\title{
Regulation of invertase in Aspergillus nidulans: effect of different carbon sources
}

\author{
Marilene H. Vainstein $\dagger$ and John F. Peberdy* \\ Department of Botany, Microbial Biochemistry and Genetics Group, University of Nottingham, \\ Nottingham NG7 2RD, UK
}

(Received 11 May 1990; revised 10 October 1990; accepted 25 October 1990)

\begin{abstract}
Aspergillus nidulans produces an extracellular $\beta$-D-fructofuranoside fructohydrolase (invertase) when grown on a medium containing the $\beta$-fructofuranosides sucrose or raffinose, indicating that synthesis is subject to induction by the substrate. On a growth medium containing sucrose, production was maximal at $15 \mathrm{~h}$ in cultures incubated at $28 \mathrm{C}^{\circ}$. After this time the level of detectable invertase in the cultures declined. A proportion of the enzyme was secreted during the linear growth phase of the fungus. Various sugars were investigated for induction of invertase, but only the two $\beta$-fructofuranosides induced high production levels; with the other sugars, the enzyme was produced only at a low constitutive level. Mycelium grown under repressive conditions (1\% glucose), rapidly produced invertase when transferred to sucrose-containing medium. After $80 \mathrm{~min}$ the invertase level in these cultures was 26-fold higher than the constitutive level. The repressive effect of other sugars, e.g. glucose and xylose, on invertase production was also demonstrated in this experimental system.
\end{abstract}

\section{Introduction}

Sucrose is utilized by almost all micro-organisms via its conversion to glucose and fructose catalysed by invertase enzymes. Two types of invertase, $\beta$-D-fructofuranosidase fructohydrolase (EC 3.2.1.26) and $\alpha$-D-glucoside glucohydrolase (EC 3.2.1.20), can be distinguished according to whether the fructose or glucose end, respectively, of the molecule is cleaved (Neuberg \& Mandl, 1950).

The formation of invertase ( $\beta$-D-fructofuranosidase fructohydrolase) by Saccharomyces cerevisiae and Neurospora crassa is primarily controlled by catabolic repression, particularly by hexoses. The effects of various levels and types of sugar have been examined in detail (Metzenberg, 1962; Sargent \& Woodward, 1969). Two sizes of active enzyme are present in Neurospora (Eilers et al., 1964; Metzenberg, 1964) and there is a preferential release of the smaller form during growth (Trevithick \& Metzenberg, 1966). Invertase biosynthesis in yeast is not inducible by its substrates but is subject to repression by the glucose concentration in the culture medium (Hackel \& Khan, 1978; Sarokin \& Carlson, 1986). Two forms of the yeast enzyme are produced: a heavily glycosylated

†Present address: Laboratorio de Microbiologia, Departamento de Biologia Celular, Universidade de Brasilia, Brasilia, DF, Brazil. form secreted into the periplasmic space and an apparently non-glycosylated form retained within the cell (Neumann \& Lampen, 1967; Gascon \& Lampen, 1968; Gascon et al., 1968; Lampen, 1968). The glycosylated form has been used as a probe for the process of glycoprotein biosynthesis and secretion (Novick et al., 1981; Trimble et al., 1983; Esmon et al., 1987).

Several factors affect invertase production in different micro-organisms and among these, glucose has been found to play an important role as repressor of synthesis. Substantial information on invertase regulation, structure and gene control exists for $S$. cerevisiae (Gascon et al., 1968; Carlson \& Botstein, 1982; Perlman et al., 1982) and N. crassa (Metzenberg, 1962; Sargent \& Woodward, 1969; Meachum et al., 1971; Casanova et al., 1987). However, few data exist concerning the enzyme produced by Aspergillus spp. (Andres \& Peberdy, 1974; Olutiola \& Cole, 1980).

Invertase content in $A$. nidulans is dependent on growth conditions and especially on carbon source. The enzyme is produced only in response to its substrates (sucrose and raffinose) and is repressed by its end products (glucose and fructose). Thus, invertase provides a good model system for investigating the production of an enzyme under dual control by induction and catabolic repression. 


\section{Methods}

Organism. Aspergillus nidulans (Eidam) strains 2.1, 2.124, 2.108 (University of Nottingham collection) and Aspergillus niger (B60) obtained from Professor Dr C. P. Kubicek (Technical University of Vienna, Austria) were used. Strains used routinely were kept at $40^{\circ} \mathrm{C}$ on malt extract/yeast extract/glucose agar (MYG) containing $\left(\mathrm{g} \mathrm{t}^{-1}\right)$ : malt extract, 5; yeast extract, 2.5; glucose, 10; agar, 20; they were subcultured regularly every 3 to 4 months.

Culture conditions. Aspergillus minimal medium (AMM)(Pontecorvo et al., 1953) was inoculated with $10^{7}$ conidia $\mathrm{ml}^{-1}$ in $250 \mathrm{ml}$ conical flasks containing $25 \mathrm{ml}$ of medium supplemented with the appropriate carbon source $(1 \%, \mathrm{w} / \mathrm{v})$ and incubated as shaken cultures at 180 r.p.m. at $28{ }^{\circ} \mathrm{C}$ for up to $24 \mathrm{~h}$. Glucose, fructose and xylose were autoclaved separately and all other sugars used were sterilized by filtration with a $0 \cdot 2 \mu \mathrm{m}$ membrane.

To test enzyme production at various growth phases, whole cultures were harvested at frequent time intervals for determination of dry weight, enzyme activity and protein. For induction experiments, 18-hold mycelium was produced in $25 \mathrm{ml}$ of AMM supplemented with $1 \%$ $(\mathrm{w} / \mathrm{v})$ glucose and transferred, after washing, to the same medium with $1 \%(\mathrm{w} / \mathrm{v})$ sucrose for a further $2 \mathrm{~h}$.

Preparation of enzyme fractions. Three enzyme fractions were derived from the cultures, namely soluble and insoluble mycelial fractions and a culture filtrate preparation. Mycelium was harvested by centrifugation at $4000 \mathrm{~g}$ for $10 \mathrm{~min}$, washed twice in ice-cold $25 \mathrm{~mm}$-Tris/phosphate buffer $\mathrm{pH} 6.7$, frozen at $-70^{\circ} \mathrm{C}$ and freeze-dried overnight. Freezedried mycelium was weighed and then ground to a fine powder with liquid nitrogen, resuspended at a concentration of $100 \mathrm{mg} \mathrm{ml}^{-1}$ in lysis buffer $[25 \mathrm{~mm}$-Tris/phosphate $\mathrm{pH} 6.7,10 \%(\mathrm{v} / \mathrm{v})$ glycerol, $0.1 \mathrm{~mm}-$ dithiothreitol, $1 \mathrm{~mm}$-EDTA and $2 \mathrm{~mm}$-phenylmethylsulphonyl fluoride, prepared as a $40 \mathrm{~mm}$ stock solution in $95 \%(\mathrm{v} / \mathrm{v})$ ethanol] (Carlson et al., 1981) and centrifuged in an Eppendorf microcentrifuge at $13000 \mathrm{~g}$ for $30 \mathrm{~min}$ at $4{ }^{\circ} \mathrm{C}$. The supernatant obtained after centrifugation was used as the soluble fraction. The pellet was washed twice by centrifugation in lysis buffer, resuspended in the same buffer and used as insoluble fraction (wall fraction).

Culture filtrates were dialysed overnight against $10 \mathrm{~mm}$-acetate buffer pH 5.0 at $4{ }^{\circ} \mathrm{C}$, to remove residual glucose before determination of enzyme activity.

Analytical determinations. Invertase was assayed by the following method: $80 \mu \mathrm{l}$ of appropriately diluted enzyme preparation was mixed with $160 \mu 10.2 \mathrm{M}$-acetate buffer pH 5.0 and $80 \mu$ l of a $0.5 \mathrm{M}$-sucrose or raffinose solution (final concentration $125 \mathrm{~mm}$ ). After incubation for $30 \mathrm{~min}$ at $30^{\circ} \mathrm{C}$ the reaction was stopped by addition of Sumner's 3,5dinitrosalicylic acid reagent $(1 \mathrm{ml})$ (Miller, 1959); the tubes were boiled for $10 \mathrm{~min}$ for colour development. Reducing sugars were estimated using glucose $\left(0 \cdot 1-0.5 \mathrm{mg} \mathrm{ml}^{-1}\right)$ as a reference standard. In this and all enzyme assays two control reactions were set up, one in which the enzyme preparation was replaced by buffer solution and the second in which the substrate solution was similarly replaced. The absorbance at $550 \mathrm{~nm}$ of the control mixtures was subtracted from the assay mixture absorbance to correct for endogenous reducing components. The suspended material in the insoluble mycelial fraction did not interfere with the spectrophotometric assays. One unit of invertase was defined as the amount of enzyme liberating $1 \mu \mathrm{mol}$ of reducing sugar (as glucose) in $1 \mathrm{~min}$ at $30^{\circ} \mathrm{C}$.

Malate dehydrogenase (EC 1.1.1.37) in the soluble mycelial and culture filtrate fractions was measured spectrophotometrically (Galbraith \& Smith, 1969). The reaction mixture contained $50 \mu 1$ of appropriately diluted enzyme preparation, $0.25 \mu \mathrm{M}-\mathrm{NADH}, 260 \mu \mathrm{M}$ phosphate buffer $\mathrm{pH} 7.4$ and $30 \mu \mathrm{M}$-oxaloacetate in a total volume of
$3 \mathrm{ml}$. One unit was defined as the amount of enzyme which converted $1 \mu \mathrm{mol}$ of oxaloacetate in $1 \mathrm{~min}$ at $25^{\circ} \mathrm{C}$.

Maltase ( $\alpha$-glucosidase; EC 3.2.1.20) activity was determined by its hydrolysis of the substrate $p$-nitrophenyl $\alpha$-D-glucopyranoside (PNPG) into $p$-nitrophenol, which is detected by its absorbance at $410 \mathrm{~nm}$ (Kratky et al., 1975). A total of $0.5 \mathrm{ml}$ of assay mixture (1 mg PNPG $\mathrm{ml}^{-1}$ in $0.05 \mathrm{M}$-phosphate buffer $\mathrm{pH} 7.0$ ) was placed in a test tube in a $37^{\circ} \mathrm{C}$ water bath. After temperature equilibration, $50 \mu \mathrm{l}$ of enzyme solution was added to start the reaction. After $30 \mathrm{~min}$ the reaction was stopped with $1 \mathrm{ml} 0 \cdot 2 \mathrm{M}-\mathrm{NaHCO}_{3}$. The absorbance was read at $410 \mathrm{~nm}$ against a distilled water blank. One unit of maltase was defined as the amount of enzyme capable of liberating $1 \mu \mathrm{mol}$ of $p$-nitrophenol min ${ }^{-1}$ at $37^{\circ} \mathrm{C}$.

Glucose was measured by the procedure of Raabo \& Terkildsen (1960), using the Sigma diagnostic kit.

Protein was determined by the method of Bradford (1976) using the Bio-Rad Protein Assay Reagent and bovine albumin as standard.

Electrophoresis procedures. Samples were prepared as described above and diluted $(1: 1)$ with twice-concentrated electrophoresis sample buffer [ $125 \mathrm{mM}$-Tris buffer $\mathrm{pH} 6.8 ; 4 \%$ (w/v) SDS; $20 \%(\mathrm{v} / \mathrm{v})$ glycerol and $0.05 \%(\mathrm{w} / \mathrm{v})$ bromophenol blue as a tracking dye], and loaded onto a $7.5 \%(\mathrm{w} / \mathrm{v})$ acrylamide slab gel (acrylamide: bisacrylamide ratio, $30: 0.8$ ) made up in $37 \mathrm{mM}$-Tris buffer $\mathrm{pH} 8.8$, plus $0.1 \%$ (w/v) SDS. The running buffer system used was $25 \mathrm{~mm}$-Tris, $192 \mathrm{~mm}-$ glycine containing $0.1 \%(w / v)$ SDS. Electrophoresis was run at a constant current at $4{ }^{\circ} \mathrm{C}$ until the tracking dye front was $0.5 \mathrm{~cm}$ from the bottom edge of the gel.

Invertase activity was detected in situ by a modification of the staining procedure of Gabriel \& Wang (1969).

Immediately after electrophoresis the gels were incubated for $1 \mathrm{~h}$ in $2.5 \%(\mathrm{v} / \mathrm{v})$ Triton $\mathrm{X}-100$ with gentle shaking at room temperature. The gels were then washed with distilled water and incubated at $30^{\circ} \mathrm{C}$ for $30 \mathrm{~min}$ in $0.1 \mathrm{M}$-sucrose in $0.1 \mathrm{M}$-acetate buffer $\mathrm{pH} 5 \cdot 0$. On completion of the enzymic reaction, the gels were thoroughly rinsed with distilled water, transferred to $0 \cdot 1 \mathrm{M}$-iodoacetamide, kept in this solution for $5 \mathrm{~min}$ at room temperature, and then rinsed well with distilled water. The gels were next immersed in a freshly prepared solution of $0.2 \%$ (w/v) 2,3,5-triphenyltetrazolium chloride monohydrate in $1 \mathrm{M}-\mathrm{NaOH}$ and heated in a boiling water bath for 1-2 min until the red formazan bands appeared. Immediately after the heating step, the gels were rinsed with distilled water, fixed for $30 \mathrm{~min}$ in $7.5 \%(\mathrm{v} / \mathrm{v})$ acetic acid and stored at $4^{\circ} \mathrm{C}$.

\section{Results}

The kinetics of invertase production are illustrated in Fig. 1. Synthesis of the enzyme was strongly influenced by the sugar used as the main carbon source. Of the sugars tested (fructose, glucose, raffinose and sucrose), only the sucrose-grown and the raffinose-grown cultures possessed invertase activity, indicating that the enzyme is substrate inducible. Under the conditions described, invertase production was greatest with young cultures $(15 \mathrm{~h})$ and fell progressively with increasing time (Fig. $1 a, b)$. Total enzyme activity increased at a rate proportional to the increase in total protein within the culture (Fig. $2 a$ ). Secretion of total protein also increased with the age of the culture (Fig. 2b). At least half of the total enzyme in the system was secreted to the culture 


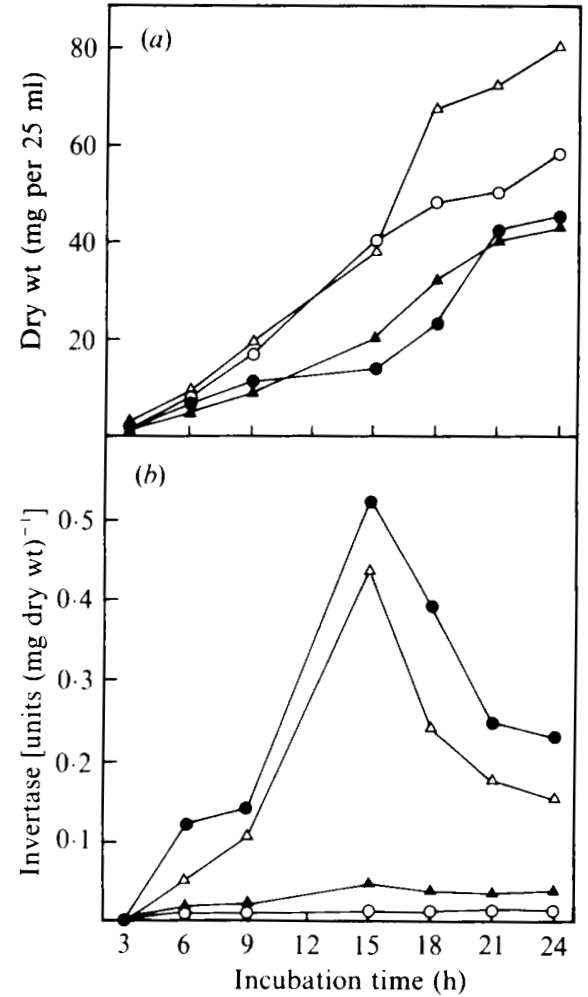

Fig. 1. Growth kinetics $(a)$ and invertase secretion $(b)$ by $A$. nidulans $(2.124)$ on different carbon sources (each $1 \%, w / v)$ : fructose $(\boldsymbol{\Delta})$, glucose $(O)$, raffinose $(O)$ and sucrose $(\triangle)$. Values are the means of triplicate flasks for each time point. Standard deviations were always less than $10 \%$ of the mean.

medium during growth. Secretion of invertase by mycelium grown on sucrose, expressed as a percentage of total enzyme, increased with the age of the culture (Fig. 3). However, enzyme synthesis declined with age, as did the concentration of free glucose in the medium (Fig. 4). Malate dehydrogenase, an essential intracellular enzyme, was not found in the culture filtrates, indicating that the invertase was truly secreted.

The mycelial soluble fraction and the secreted enzymes had the same optimum $\mathrm{pH}(5 \cdot 2)$ and temperature $\left(60^{\circ} \mathrm{C}\right)$ values for the reaction, indicating that they are the same protein (M. H. Vainstein, L. M. Boddy \& J. F. Peberdy, unpublished results). The enzyme hydrolysed sucrose and raffinose, showing it to be a $\beta$ fructofuranosidase. No maltase activity was found in the system under the conditions tested.

Experiments were carried out to verify the regulatory effect of sucrose and glucose on invertase synthesis and secretion. Mycelium grown overnight on glucose/salts medium was harvested by centrifugation, washed twice in the salts medium, transferred to a fresh medium with sucrose or glucose as a carbon source, and incubated for a further $80 \mathrm{~min}$. As shown in Table 1, glucose did not
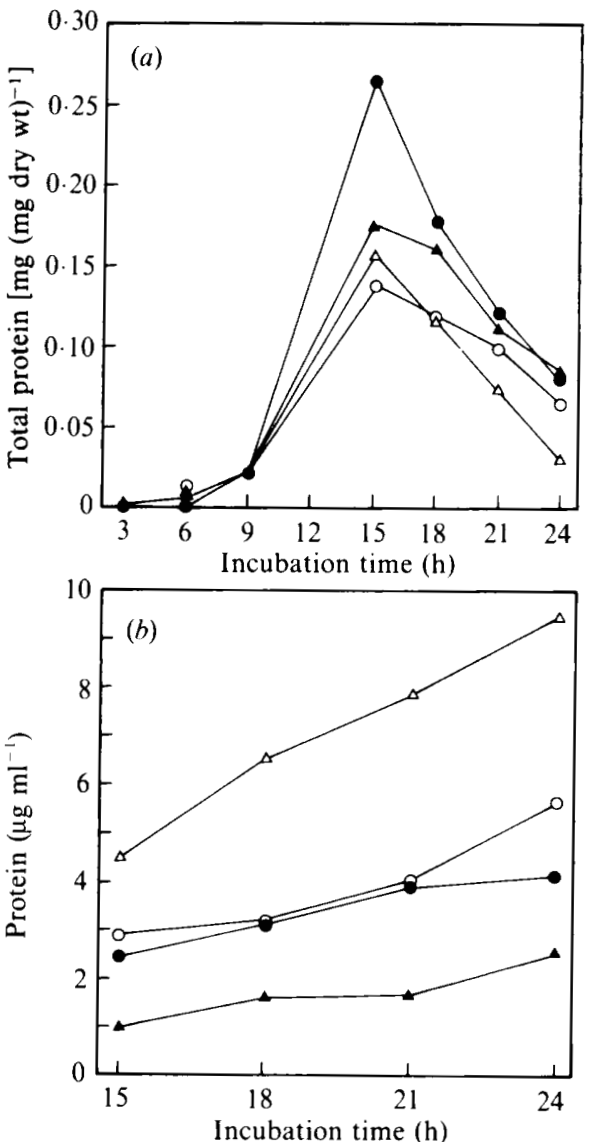

Fig. 2. Effect of carbon source $(1 \%, w / v)$ on the total protein content $(a)$ and protein secretion $(b)$ in $A$. nidulans strain 2.124 : fructose $(\boldsymbol{\Delta})$, glucose $(O)$, raffinose $(\Theta)$ and sucrose $(\triangle)$. Values are the means of triplicate flasks for each time point. Standard deviations were always less than $10 \%$ of the mean.

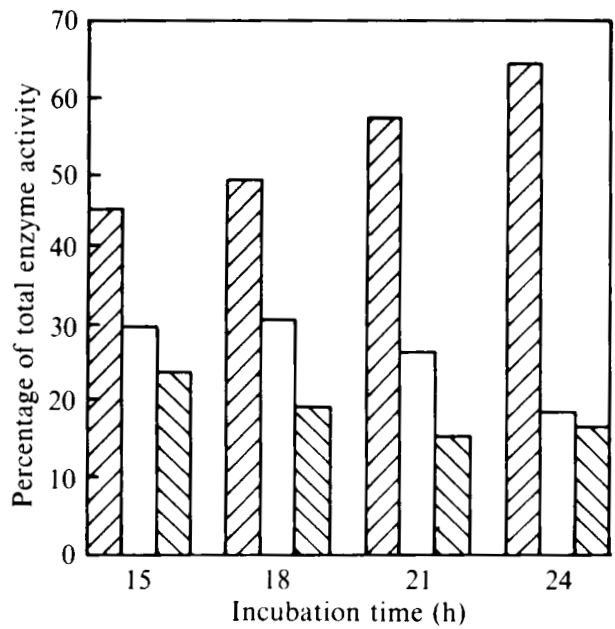

Fig. 3. Percentage of invertase present in different fractions of $A$. nidulans strain 2.124 during growth on $1 \%(\mathrm{w} / \mathrm{v})$ sucrose medium. Secreted enzyme; $\square$, mycelial soluble fraction; $\mathbb{N}$, mycelial insoluble fraction (see Methods). 


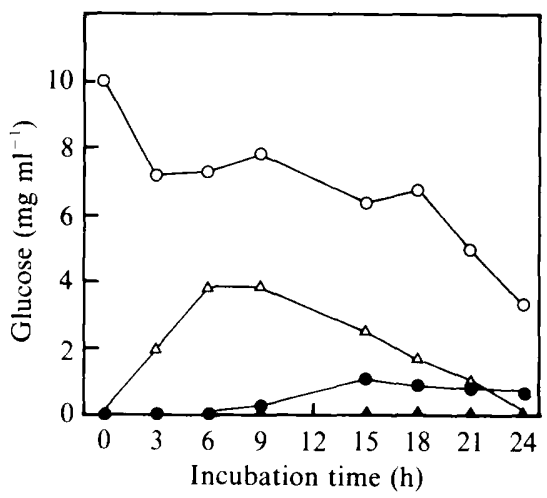

Fig. 4. Free glucose present in the medium during growth of $A$. nidulans strain 2.124 on different carbon sources (each $1 \%, \mathrm{w} / \mathrm{v}$ ): fructose $(\boldsymbol{\Delta})$, glucose $(\bigcirc)$, raffinose $(\boldsymbol{O})$ and sucrose $(\triangle)$.

promote an increase in specific activity of invertase but sucrose did. After $80 \mathrm{~min}$ incubation on sucrose medium, a 26-fold increase in the total enzyme activity was noted compared with the levels on glucose medium. PAGE analysis of these samples showed that the mycelial soluble fraction and the secreted enzymes migrate at the same position in the gels (Fig. 5a). These effects on enzyme induction were verified in three different $A$. nidulans strains and $\boldsymbol{A}$. niger. Data in Table 2 show a large difference in specific activity in all three $A$. nidulans strains as well as in $A$. niger. Among the $A$. nidulans strains tested, the wild-type was the best producer of invertase. However, this was still low compared with $A$. niger, but the levels of secretion were very similar (60.69 and $58.88 \%$, respectively). $A$. niger possesses two forms of invertase instead of the one form normally observed in $A$. nidulans strains (Fig. $5 b$ ).

Once the inducibility of invertase synthesis and secretion by sucrose was known it was of interest to investigate the effect of other carbohydrates. The experimental protocol previously described was followed using the strain of $A$. nidulans best for invertase production.

As shown in Fig. 6, the lowest level of total invertase units was found in cultures with $3 \%(\mathrm{w} / \mathrm{v})$ glucose. Low values for activity were also found for $0.05 \% \mathrm{v}(\mathrm{w} / \mathrm{v})$ glucose but, interestingly, secretion of invertase could also be detected. Maltose, melibiose, glycerol and trehalose (all at $1 \%, w / v$ ) induced invertase to the same extent. Raffinose and sucrose were the best inducers but raffinose seemed to be the best carbon source for secretion of invertase. PAGE analysis showed the same form of enzyme produced on all sugars tested (data not shown). The samples were also screened for the presence of maltase, a sucrose-hydrolysing intracellular enzyme found in the same fungi. No activity was detected under the conditions used.

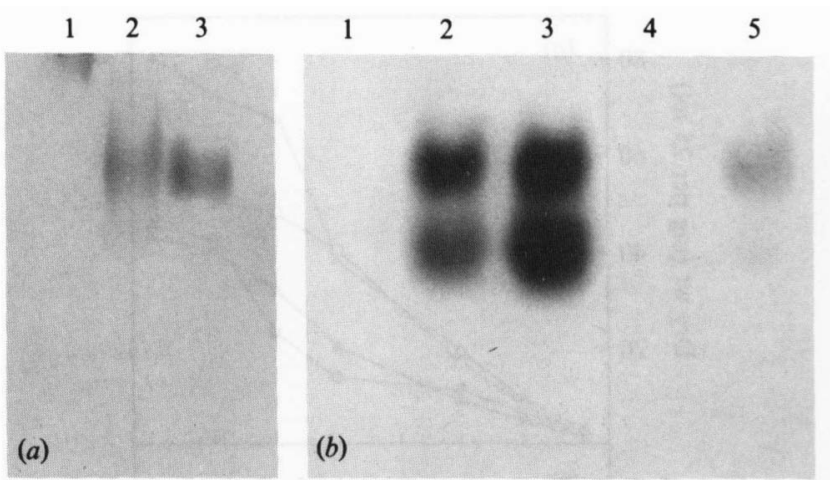

Fig. 5. Electrophoretic analysis in a $7.5 \%$ SDS non-denaturing gel of invertases from $A$. nidulans $(a)$ and $A$. niger $(b)$. (a) Lane 1 , yeast invertase; lane 2 , invertase secreted into the culture filtrate; lane 3 , invertase present in the mycelial soluble fraction. (b) Lane 1, mycelial soluble fraction prepared from mycelium incubated for $120 \mathrm{~min}$ in medium containing $1 \%(\mathrm{w} / \mathrm{v})$ glucose; lanes 2 and 3 , mycelial soluble fraction prepared from mycelium incubated for $45 \mathrm{~min}(2)$ and $120 \mathrm{~min}$ (3) in medium containing $1 \%(w / v)$ sucrose; lanes 4 and 5 , mycelial insoluble fraction prepared from mycelium incubated for $120 \mathrm{~min}$ in medium containing $1 \%(\mathrm{w} / \mathrm{v})$ glucose $(4)$ or sucrose $(5)$. The gels were stained for invertase activity as described in Methods.

The effect of sugar mixtures on invertase expression was investigated to confirm the repressive effect of a range of concentrations of glucose, fructose and xylose, in the presence of a fixed concentration of sucrose. Mycelium produced in AMM with $3 \%(\mathrm{w} / \mathrm{v})$ glucose was washed as before and transferred to fresh AMM medium containing the sugar mixtures. As shown in Table 3, sucrose $(1 \%, w / v)$ alone gave the highest production of invertase, the effect being significantly higher than that of various mixed sugars, according to Tukey's test at $5 \%$ probability. Glucose, $5 \%(\mathrm{w} / \mathrm{v})$, had the most repressive effect in the presence of $1 \%(\mathrm{w} / \mathrm{v})$ sucrose. The levels of enzyme produced in $5 \%$ fructose or xylose were similar to those obtained with $1 \%$ and $3 \%(\mathrm{w} / \mathrm{v})$ glucose (Table 3 ).

In another set of experiments, mycelium grown overnight in $1 \%(\mathrm{w} / \mathrm{v})$ sucrose medium was transferred to a fresh medium containing sucrose $(1 \%, \mathrm{w} / \mathrm{v})$ or glucose $(1 \%, w / v)$ and incubated for a further $80 \mathrm{~min}$ as shaken cultures. As shown in Table 4, invertase continued to be actively synthesized and secreted in sucrose medium. However, in the presence of glucose, synthesis of invertase was severely repressed and secretion was not observed during the course of the experiment.

\section{Discussion}

The existence of external hydrolytic enzymes in microorganisms might be attributed to the impermeability of the cell membrane to their corresponding substrates. 


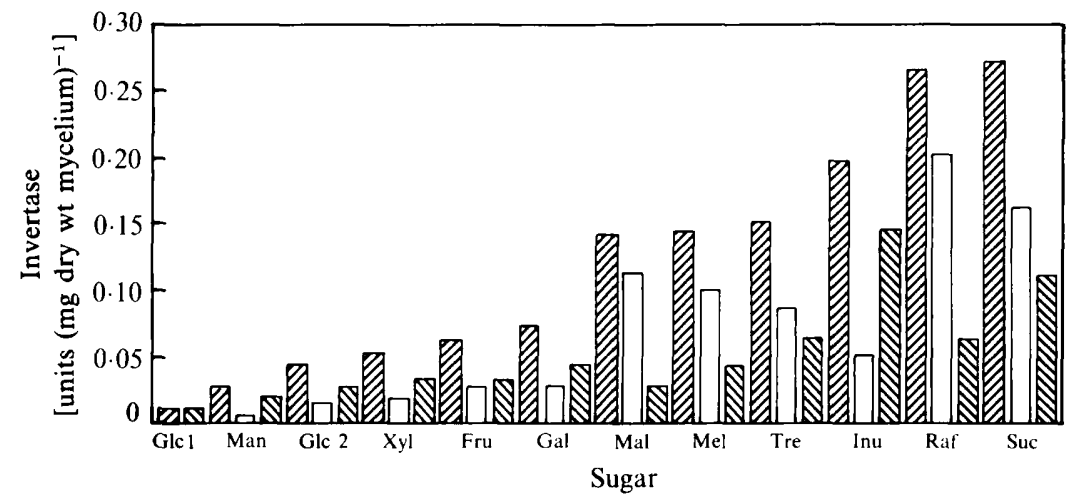

Fig. 6. Effect of different sugars on invertase expression in A. nidulans strain 2.1. Total enzyme activity in the system; $\mathbb{N}$, mycelial soluble fraction; $\square$, enzyme secreted into the culture medium. Abbreviations: Glc 1, 3\% glucose; Man, $1 \%$ mannose; Glc 2, $0.05 \%$ glucose; Xyl, $1 \%$ xylose; Fru, $1 \%$ fructose; Gal, $1 \%$ galactose; Mal, $1 \%$ maltose; Mel, $1 \%$ melibiose; Tre, $1 \%$ trehalose; Inu, $1 \%$ inulin; Raf, $1 \%$ raffinose; Suc, $1 \%$ sucrose.

Table 1. Effect of glucose and sucrose on invertase synthesis in A. nidulans strain 2.124

\begin{tabular}{|c|c|c|c|c|c|c|c|c|}
\hline \multirow{3}{*}{$\begin{array}{l}\text { ncubation } \\
\text { time } \\
\text { (min) }\end{array}$} & \multicolumn{8}{|c|}{ Invertase [units (mg dry wt mycelium) ${ }^{-1}$ ] } \\
\hline & \multicolumn{4}{|c|}{ Sucrose $(1 \%, w / v)$} & \multicolumn{4}{|c|}{ Glucose $(1 \%, w / v)$} \\
\hline & Total & $\mathrm{CF}$ & Sol. & Insol. & Total & $\mathrm{CF}$ & Sol. & Insol. \\
\hline 20 & $0 \cdot 005$ & 0 & $\begin{array}{l}0.001[25 \%] \\
( \pm 7 E-4)\end{array}$ & $\begin{array}{l}0.004[75 \%] \\
( \pm 1 E-3)\end{array}$ & $0 \cdot 005$ & 0 & $\begin{array}{l}0.001[25 \%] \\
( \pm 7 \mathrm{E}-4)\end{array}$ & $\begin{array}{l}0.004[75 \%] \\
( \pm 1 E-3)\end{array}$ \\
\hline 45 & 0.063 & $\begin{array}{l}0.024[38 \%] \\
( \pm 1 \cdot 7 \mathrm{E}-3)\end{array}$ & $\begin{array}{l}0.027[43 \%] \\
( \pm 2 \cdot 1 \mathrm{E}-3)\end{array}$ & $\begin{array}{l}0.012[19 \%] \\
( \pm 2 \cdot 8 \mathrm{E}-3)\end{array}$ & $0 \cdot 007$ & 0 & $\begin{array}{l}0.002[28 \%] \\
( \pm 7 \cdot 1 \mathrm{E}-4)\end{array}$ & $\begin{array}{l}0.005[72 \%] \\
( \pm 7.0 \mathrm{E}-4)\end{array}$ \\
\hline 80 & $0 \cdot 127$ & $\begin{array}{l}0.051[40 \%] \\
( \pm 1.5 \mathrm{E}-3)\end{array}$ & $\begin{array}{l}0.052[41 \%] \\
( \pm 2 E-3)\end{array}$ & $\begin{array}{l}0.024[19 \%] \\
( \pm 1 \cdot 3 \mathrm{E}-3)\end{array}$ & $0 \cdot 007$ & 0 & $\begin{array}{l}0.002[28 \%] \\
( \pm 7 \mathrm{E}-4)\end{array}$ & $\begin{array}{l}0.005[72 \%] \\
( \pm 7 E-4)\end{array}$ \\
\hline
\end{tabular}

Table 2. Induction of invertase by $1 \%(w / v)$ sucrose in different $A$. nidulans strains and $A$. niger

Values are the means of triplicate flasks for each time point, \pm standard deviation (E, exponential). ND, Not determined.

\begin{tabular}{lccc}
\hline \hline & \multicolumn{3}{c}{ Invertase [units (mg dry wt mycelium) ${ }^{-1}$ ] } \\
\cline { 2 - 4 } & $\begin{array}{c}\text { Culture } \\
\text { filtrate }\end{array}$ & $\begin{array}{c}\text { Soluble } \\
\text { fraction }\end{array}$ & $\begin{array}{c}\text { Insoluble } \\
\text { fraction }\end{array}$ \\
\hline A. nidulans 2.1 & $0.244 \pm 8 \cdot 1 \mathrm{E}-3$ & $0.136 \pm 2 \cdot 0 \mathrm{E}-3$ & $0.022 \pm 1.5 \mathrm{E}-3$ \\
A. nidulans 2.108 & $\mathrm{ND}$ & $0.027 \pm 1 \cdot 4 \mathrm{E}-3$ & $0.008 \pm 7 \cdot 0 \mathrm{E}-4$ \\
A. nidulans 2.124 & $0.051 \pm 1 \cdot 5 \mathrm{E}-3$ & $0.052 \pm 2 \cdot 0 \mathrm{E}-3$ & $0.024 \pm 1 \cdot 3 \mathrm{E}-3$ \\
A. niger $\mathrm{B} 60$ & $0.368 \pm 3 \cdot 6 \mathrm{E}-3$ & $0.175 \pm 3 \cdot 0 \mathrm{E}-3$ & $0.082 \pm 2.0 \mathrm{E}-3$ \\
\hline \hline
\end{tabular}

Some of these enzymes are formed only in the presence of their specific substrates. This situation may pertain to invertase formation in $A$. nidulans, where the enzyme appeared in high levels only in response to the presence of $\beta$-fructofuranosides (sucrose and raffinose), which are its normal substrates. In contrast, synthesis and secretion of invertase by the slime strain of Neurospora crassa occurred independently of the carbon source present in the culture medium, whereas catabolic repression was normal in the wild-type strain (Casanova et al., 1987). Synthesis of the larger, extracellular form of invertase in S. cerevisiae (Carlson \& Botstein, 1982) and Aspergillus flavus (Olutiola \& Cole, 1980) are also subject to catabolic repression.

The maximal invertase activity in $A$. nidulans was found about $15 \mathrm{~h}$ after inoculation into medium containing sucrose or raffinose, simultaneously with the peak of protein accumulation in the culture. In medium with 
Table 3. Effect of different concentrations of glucose, xylose and fructose in the presence of $1 \%$ sucrose on invertase synthesis in A. nidulans strain 2.1

Values are the means of triplicate flasks for each variation \pm standard deviation (E, exponential); numbers followed by different superscript letters are statistically different at $5 \%$ probability according to Tukey's test.

\begin{tabular}{lc}
\hline \hline \multicolumn{1}{c}{ Sugar } & $\begin{array}{c}\text { Invertase activity } \\
\text { [units (mg dry wt mycelium) }\end{array}$ \\
\hline Sucrose & $0 \cdot 2720^{c} \pm 7 \cdot 0 \mathrm{E}-3$ \\
Sucrose $+1 \%$ Glucose & $0 \cdot 2010^{a b} \pm 1 \cdot 5 \mathrm{E}-2$ \\
Sucrose $+3 \%$ Glucose & $0 \cdot 1780^{a b} \pm 1 \cdot 0 \mathrm{E}-2$ \\
Sucrose $+5 \%$ Glucose & $0 \cdot 1495^{a} \pm 2 \cdot 1 \mathrm{E}-2$ \\
Sucrose $+1 \%$ Fructose & $0 \cdot 2205^{b c} \pm 1 \cdot 7 \mathrm{E}-2$ \\
Sucrose $+3 \%$ Fructose & $0 \cdot 1845^{a b} \pm 9 \cdot 1 \mathrm{E}-3$ \\
Sucrose $+5 \%$ Fructose & $0 \cdot 2005^{a b} \pm 1 \cdot 4 \mathrm{E}-2$ \\
Sucrose $+1 \%$ Xylose & $0 \cdot 2145^{b c} \pm 2 \cdot 3 \mathrm{E}-2$ \\
Sucrose $+3 \%$ Xylose & $0 \cdot 1975^{a b} \pm 1 \cdot 3 \mathrm{E}-2$ \\
Sucrose $+5 \%$ Xylose & $0 \cdot 1830^{a b} \pm 1 \cdot 0 \mathrm{E}-2$ \\
\hline \hline
\end{tabular}

sucrose, the decrease of invertase activity seems to be related to the depletion of the carbon source for mycelium growth. If low concentrations of free glucose in the medium, released in the breakdown of sucrose, caused derepression of synthesis, then higher levels of invertase activity would be expected after growth over $15 \mathrm{~h}$, when the glucose levels in the culture were reaching their lowest values. The results suggested that secretion of invertase might be related to low levels of free glucose in the medium and the age of the mycelium. The percentage of the enzyme secreted increased proportionally with the age of the culture and the simultaneous decrease of both enzyme synthesis and glucose concentration.
The trisaccharide raffinose supported cultures with the highest invertase activity. In this respect, $A$. nidulans had a similar behaviour to Neurospora (Metzenberg, 1962) and this may be related to the absence of free glucose among the enzymic cleavage products of raffinose. The ability of $A$. nidulans to synthesize very low levels of invertase in fructose medium indicates that fructose may suffice as a carbon source for the initial synthesis of the enzyme (Gupta \& Bhatia, 1982). However, subsequent synthesis depends on the presence of sucrose or raffinose in the medium.

Transfer and induction experiments showed the production of a constitutive level of invertase in a wide range of sugars, with $3 \%$ glucose giving the lowest activities and $1 \%$ raffinose and sucrose the highest. A low concentration of glucose $(0.05 \%)$ did not cause significant derepression or induction of invertase. In this respect invertase synthesis in $A$. nidulans differs from that in $S$. cerevisiae, where production of the secreted enzyme is highly regulated by the concentration of glucose present in the medium. Cells grown in medium containing high levels of glucose do not produce and secrete invertase, but a shift to medium containing low glucose concentrations causes derepression (Hackel, 1975; Hackel \& Khan, 1978; Carlson, 1984).

Using mixtures of sugars with a range of levels of the repressor, the repressive effect of glucose on invertase synthesis was less. Even at glucose concentrations as high as $5 \%$ the enzyme continued to be synthesized and secreted as long as the inducer was present. This evidently suggests that a correlation between the molecular structure of the inducer and the catalytic centre on the enzyme is inherently involved in the mechanisms of induction (Jacob \& Monod, 1961). The signal leading to induction of synthesis of invertase could

Table 4. Effect of glucose and sucrose on invertase synthesis in A. nidulans strain 2.124

Abbreviations: CF, culture filtrate; Sol., mycelial soluble fraction (see Methods). Numbers in parentheses are standard deviations for the mean of triplicate flasks for each time point $(\mathrm{E}$, exponential).

\begin{tabular}{|c|c|c|c|c|c|c|}
\hline \multirow{3}{*}{$\begin{array}{c}\text { Incubation } \\
\text { time } \\
\text { (min) }\end{array}$} & \multicolumn{6}{|c|}{ Invertase [units (mg dry wt mycelium $)^{-1}$ ] } \\
\hline & \multicolumn{3}{|c|}{ Sucrose $(1 \%, w / v)$} & \multicolumn{3}{|c|}{ Glucose $(1 \%, w / v)$} \\
\hline & Total & $\mathrm{CF}$ & Sol. & Total & $\mathrm{CF}$ & Sol. \\
\hline 0 & $\begin{array}{l}0 \cdot 117 \\
( \pm 2 E-2)\end{array}$ & 0 & $\begin{array}{l}0 \cdot 117 \\
( \pm 2 E-2)\end{array}$ & $\begin{array}{l}0 \cdot 117 \\
( \pm 2 E-2)\end{array}$ & 0 & $\begin{array}{l}0 \cdot 117 \\
( \pm 2 E-2)\end{array}$ \\
\hline 20 & $\begin{array}{l}0 \cdot 178 \\
( \pm 2 E-3)\end{array}$ & $\begin{array}{l}0 \cdot 142 \\
( \pm 3 E-3)\end{array}$ & $\begin{array}{l}0.035 \\
( \pm 2 E-3)\end{array}$ & $\begin{array}{l}0.072 \\
( \pm 7 E-3)\end{array}$ & 0 & $\begin{array}{l}0.072 \\
( \pm 7 E-3)\end{array}$ \\
\hline 45 & $\begin{array}{l}0 \cdot 355 \\
( \pm 2 E-3)\end{array}$ & $\begin{array}{l}0 \cdot 255 \\
( \pm 7 E-3)\end{array}$ & $\begin{array}{l}0 \cdot 100 \\
( \pm 9 E-3)\end{array}$ & $\begin{array}{l}0.078 \\
( \pm 5 E-3)\end{array}$ & 0 & $\begin{array}{l}0.078 \\
( \pm 5 E-3)\end{array}$ \\
\hline 80 & $\begin{array}{l}0.461 \\
( \pm 1 E-2)\end{array}$ & $\begin{array}{l}0.351 \\
( \pm 1 E-2)\end{array}$ & $\begin{array}{l}0 \cdot 110 \\
( \pm 4 E-3)\end{array}$ & $\begin{array}{l}0.081 \\
( \pm 4 E-3)\end{array}$ & 0 & $\begin{array}{l}0.081 \\
( \pm 4 E-3)\end{array}$ \\
\hline
\end{tabular}


result from the binding of the substrate to the cell membrane, or from the appearance in the cytoplasm of hydrolysis products of the substrate, resulting from the presence of constitutive levels of invertase on the cell surface.

The absence of a smaller internal form of invertase in the mycelium of $A$. nidulans and the presence of two forms in $A$. niger, together with the fact that all three enzymes are glycoproteins (Vainstein, 1990), shows that the currently accepted model for the synthesis and subcellular location of invertase in $S$. cerevisiae may not be extrapolated to these filamentous fungi. In $S$. cerevisiae a single structural gene codes for two different polypeptides, one of which is glycosylated and then secreted and the other remains free of carbohydrate in the cytosol (Perlman \& Halvorson, 1981; Rodriguez et al., 1981 ; Carlson \& Botstein, 1982; Perlman et al., 1982).

M.H.V. was supported by Conselho Nacional de Desenvolvimento Cientifico e Tecnologico, Brazil.

\section{References}

ANDRES, I. \& Peberdy, J. F . (1974). The production of invertase in Aspergillus nidulans with reference to the effects of glucose and sucrose. Microbios 10, 15-23.

BRADFORD, M. M. (1976). A rapid and sensitive method for the quantitation of microgram quantities of protein utilizing the principle of protein-dye binding. Analytical Biochemistry 72, 248-254.

CarLSON, M. (1984). A single SUC gene encodes both cytoplasmic and secreted invertase in Saccharomyces. Protein Transport and Secretion 341-344.

Carlson, M. \& Botstein, D. (1982). Two differentially regulated mRNAs with different $5^{\prime}$ ends encode secreted and intracellular forms of yeast invertase. Cell 28, 145-154.

Carlson, M., Osmond, B. C. \& Botstein, D. (1981). Mutants of yeast defective in sucrose utilization. Genetics 98, 25-40.

Casanova, M., Martinez, J. P., Gil, M. L., Sentandreu, R. \& RuizHerRera, J. (1987). Different molecular forms of invertase in the slime variant of Neurospora crassa: comparison with the wild-type strain. Journal of General Microbiology 133, 2447-2456.

Eilers, F. I., Allen, J., Hill, E. P. \& Sussman, A. S. (1964). Localization of disaccharidases in extracts of Neurospora after electrophoresis in polyacrylamide gels. Journal of Histochemistry and Cytochemistry 12, 448-450.

Esmon, P . C., Esmon, B. E., Schauer, I . E., Taylor, A. \& Schekman, R. (1987). Structure, assembly, and secretion of octameric invertase. Journal of Biological Chemistry 262, 4387-4394.

Gabriel, O. \& WANG, S. F. (1969). Determination of enzymatic activity in polyacrylamide gels. I. Enzymes catalyzing the conversion of nonreducing substrates to reducing products. Analytical Biochemistry 27, 545-555.

GalbRaith, J. C. \& Smith, J. E. (1969). Changes in activity of certain enzymes of the tricarboxylic acid cycle and the glyoxylate cycle during the initiation of conidiation of Aspergillus niger. Canadian Journal of Microbiology 15, 1207-1212.

GASCON, S. \& LAMPEN, O. (1968). Purification of internal invertase of yeast. Journal of Biological Chemistry 243, 1567-1572.

Gascon, S., Neumann, N. P. \& Lampen, O. (1968). Comparative study of the properties of the purified internal and external invertases from yeast. Journal of Biological Chemistry 243, 1573-1577.
Gupta, A. K. \& Bhatia, I. S. (1982). Glucofructosan biosynthesis in Fusarium oxysporum: regulation and substrate specificity of fructosyl transferase and invertase. Phytochemistry 21, 1249-1253.

HACKEL, R. A. (1975). Genetic control of invertase formation in Saccharomyces cerevisae. I. Isolation and characterization of mutants affecting sucrose utilization. Molecular and General Genetics 140, $361-370$.

HaCkel, R. A. \& Khan, N. A. (1978). Genetic control of invertase formation in Saccharomyces cerevisiae. II. Isolation and characterization of mutants conferring invertase hyperproduction in strain EK6B carrying the SUC3 Gene. Molecular and General Genetics 164, 295-302.

$J_{A C O B}$, F. \& MONOD, F. (1961). Genetic regulatory mechanisms in the synthesis of protein. Journal of Molecular Biology 3, 318-356.

KratKy, Z., Biely, P. \& Bauer, S. (1975). Mechanism of 2-deoxy-Dglucose inhibition of cell-wall polysaccharide and glycoprotein biosynthesis in Saccharomyces cerevisiae. European Journal of Biochemistry 54, 459-467.

LAMPEN, J. O. (1968). External enzymes of yeast: their nature and formation. Antonie van Leeuwenhoek 34, 1-18.

Meachum, Z. D. JR, Colvin, H. J. JR \& BRaymer, H. D. (1971). Chemical and physical studies of Neurospora crassa invertase. Molecular weight, amino acid and carbohydrate composition and quaternary structure. Biochemistry 10, 326-332.

METZENBERG, R. L. (1962). A gene affecting the repression of invertase and trehalase in Neurospora. Archives of Biochemistry and Biophysics 96, 468-474.

METZENBERG, R. L. (1964). Enzymically active subunits of Neurospora invertase. Biochimica et Biophysica Acta 89, 291-302.

MilleR, G. L. (1959). Use of dinitrosalicylic acid reagent for determination of reducing sugars. Analytical Chemistry 31, 426-428.

Neuberg, C. \& MandL, I. (1950). Invertase. In The Enzymes, pp. 527550. Edited by J. B. Sumner \& K. Myrback. London \& New York: Academic Press.

Neumann, N. P. \& Lampen, O. (1967). Purification and properties of yeast invertase. Biochemistry 6, 468-475.

Novick, P., Novick, F. S. \& Schekman, R. (1981). Order of events in the yeast secretory pathway. Cell 25, 461-469.

Olutiola, P. O. \& Cole, O. O. (1980). Extracellular invertase from Aspergillus flavus. Physiologia Plantarum 50, 26-31.

Perlman, D. \& Halvorson, H. O. (1981). Distinct repressible mRNA for cytoplasmic and secreted yeast invertase are encoded by a single gene. Cell 25, 525-536.

Perlman, D., Halvorson, H. O. \& Cannon, L. E. (1982). Presecretory and cytoplasmic invertase polypeptides encoded by distinct $m$ RNAs derived from the same structural gene differ by a signal sequence. Proceedings of the National Academy of Sciences of the United States of America 79, 781-785.

Pontecorvo, G., Roper, J. A., Hemmons, L . M., MacDonald, K. D. \& Bufton A. W. J. (1953). The genetics of Aspergillus nidulans. Advances in Genetics 5, 141-238.

RAABO, E. \& TERKILDSEN, T. C. (1960). On the enzymatic determination of blood glucose. Scandinavian Journal of Clinical Laboratory Investigation 12, 402-405.

Rodriguez, L., LAMPEN, J. O. \& MaCKay, V. L. (1981). SUCl gene of Saccharomyces: a structural gene for the large (glycoprotein) and small (carbohydrate-free) forms of invertase. Molecular and Cellular Biology 1, 469-474.

Sargent, M. L. \& Woodward, D. O. (1969). Gene-enzyme relationships in Neurospora invertase. Journal of Bacteriology 97 , 867-872.

SAROKIN, L. \& CARLSON, M. (1986). Short repeated elements in the upstream regulatory region of the $S U C 2$ gene of Saccharomyces cerevisiae. Molecular and Cellular Biology 6, 2324-2333.

TRevithick, J. R. \& MetZenberg, R. L. (1966). Molecular sieving by Neurospora cell walls during secretion of invertase isoenzymes. Journal of Bacteriology 92, 1010-1015.

Trimble, R. B., Maley, F. \& ChU, F. K. (1983). Glycoprotein biosynthesis in yeast. Journal of Biological Chemistry 258, 2562-2567.

VAINSTEIN, M. H. (1990). Regulation and characterisation of invertase in Aspergillus nidulans. PhD thesis, University of Nottingham. 